\title{
Effects of perfluorooctane sulfonate compounds on the biochemical activities in mussels (Mytilus galloprovincialis)
}

\section{Perflorooktan sülfonat (PFOS)'ın midyelerde (Mytilus galloprovincialis) biyokimyasal etkilerinin incelenmesi}

\author{
Gizem Gülsever ${ }^{1} \bullet$ Hatice Parlak ${ }^{2 *}$ \\ 'Ege University, Faculty of Fisheries, Marine Biology Department, Bornova/Izmir-Turkey iD https://orcid.org/0000-0001-7526-6207 \\ ${ }^{2}$ Ege University, Faculty of Fisheries, Marine Biology Department, Bornova/Izmir-Turkey iD https://orcid.org/0000-0002-7623-9662 \\ *Corresponding author: hatice.parlak@ege.edu.tr
}

Received date: 21.02 .2018

Accepted date: 06.09.2018

\section{How to cite this paper:}

Gülsever, G. \& Parlak, H. (2018). Effects of perfluorooctane sulfonate compounds on the biochemical activities in mussels (Mytilus galloprovincialis). Ege Journal of Fisheries and Aquatic Sciences, 35(4), 417-422. DOI:10.12714/egejfas.2018.35.4.07

\begin{abstract}
Our environment has been affected by increasing level of discharged organic and inorganic pollutants from anthropogenic sources. Perfluorinated compounds (PFCs) are one of the important sources of pollution and they are major risks for the aquatic ecosystems. The aim of this study is to determine the effects of PFOS on GST enzyme activities in mussels (Mytilus galloprovincialis). For this purpose, mussels were exposed to six different PFOS concentrations and the effects were evaluated. PFOS has been caused to a statistically significant increase in GST activity in hepatopancreas in all experimental groups compared with the control group. In conclusion, it has been approved that GST which is a defense mechanism of organisms, can be a very useful tool to detect the toxic effects of pollutants.
\end{abstract}

Keywords: Perfluorinated compounds, perfluorooctane sulfonate, mussels, Mytilus galloprovincialis, GST enzyme activity

Öz: İnsan aktiviteleri sonucunda, çevremiz her geçen gün gittikçe artan konsantrasyonda organik ve inorganik kirleticilere maruz kalmaktadır. Bu koşullarda, sucul ekosistemler açısından büyük risk oluşturan perflorlu bileşikler önemli bir yer tutmaktadır. Çalışmanın amacı, PFOS'un midyede (Mytilus galloprovincialis) GST enzim aktivitesi üzerine etkilerini belirlemektir. Bu amaçla, midyeler 6 farklı PFOS konsantrasyonuna maruz bırakılmış ve etkileri değerlendirilmiştir. Sonuç olarak, midye hepatopankreasında GST enzim aktivitesinin bütün deneme gruplarında kontrole göre istatistiksel olarak anlamlı bir yükselme gösterdiği bulunmuştur ve midyelerin korunma mekanizması olarak GST'nin, kirleticilerin toksik etkilerini belirlemek için yararlı bir araç olduğu ortaya konulmuştur.

Anahtar kelimeler: Perflorlu bileşikler, perflorooktan sülfonat, midye, Mytilus galloprovincialis, GST enzim aktivitesi 


\section{INTRODUCTION}

The aquatic environment is affected by different sources of pollution like domestic, industrial wastes and residue of human agricultural practices. Unfortunately, this ecological problem perceived as a universal problem nearly after the industrial revolution of the 1750s. The chemicals were increasingly used to enhance our daily life comfort in various fields. Researchers have paid more attention and give priority to the studies related with deleterious effects of chemicals such as persistent organic pollutants (POPs) on ecosystems, since the concentrations of organic and inorganic pollutants from anthropogenic sources in the environment have been increasing. Effects of different pollutants can be assessed by various bio tests like AMES/Salmonella mutagenicity test (Boyacıoğlu et al., 2007), embryotoxicity test with sea urchins (Karaaslan et al., 2012; Gunduz et al., 2013) or algal growth inhibition assay (Katalay et al., 2012).

POPs are the priority pollutants that pose a risk to aquatic ecosystems and human health due to biomagnification through aquatic food chain. The usage of POPs was restricted in 2004 by the Stockholm Convention. Perfluorinated compounds, particularly PFOS are widely used in the industrial applications, such as protective coatings of carpets, furniture, paper and textile as well as in the polytetrafluoroethylene products, and fire-fighting foams (Ahrens and Bundschuh 2014). Perfluoroalkyl and polyfluoroalkyl substances (PFASs) have been detected in many compartments of ecosystems due to the gross usage for almost 60 years (Houde et al., 2011; Wang et al., 2015; Yamashita et al., 2005). Some of the PFASs are listed in the national and international regulations because of bioaccumulative and toxic nature (OECD, 2002). Perfluorooctanesulfonic acid (PFOS) were added to Stockholm Convention's Annex B in 2009 and then its production and usage gradually decreased. Although, Zhao et al (2017) reported that major global manufacturers of perfluorooctanoic acid (PFOA) and its precursors were promised to voluntarily stop their production in 2015 (Zhao et.al, 2017; EPA, 2010), the releases of PFASs continue (Kwok et al., 2015; Müller et al., 2011). PFOS have strong carbon fluorine bonds and have lipophobic and hydrophilic characteristics (Kissa, 2001; Lindstrom et al., 2011). Ionic PFASs are resistant to photolysis, pyrolysis, hydrolysis and biotransformation. Thus they are highly persistent component in the environment (Kissa, 2001; Han et al., 2015).

As a result of this, PFOS has been detected in various environments such as air, sediments and water (Yeung et al, 2006; Kovarova et al., 2012; Naile et al., 2010). Paul et al. (2009) had reviewed that "total historical worldwide production of POSF was estimated to be 96 $000 \mathrm{t}$ (122 $000 \mathrm{t}$, including unusable wastes) between 1970-2002. Estimated global release of production were $45250 \mathrm{t}$ to air and water 1970-2012 from direct (manufacture, use, and consumer products) and indirect (PFOS precursors and/or impurities) sources. The various ecological studies confirm that a large part of perfluorinated compounds were found in surface waters, especially in the oceans (Prevedouros et al., 2006). Several studies on terrestrial and aquatic species showed that these compounds lead to toxic effects in living organisms (O'Brien et al., 2009; Huang et al., 2010; Boudreau et al., 2003).

In order to find out harmful effects of pollutants, back ground information is necessary at different trophic levels. Biomarkers is considered the most promising tools for ecotoxicological applications because of their ability to identify causal mechanisms that is potentially responsible for effects at higher levels of organization (Peakall and Walker, 1994; Adams, 2002). Generally, GST enzyme activities are included in this group of biomarkers and it catalyzes the conjugation of glutathione with xenobiotic, including perfluorinated compounds (Jemec et al.,2010). Oxidative stress and antioxidant enzymes are widely used as biomarkers in mussels. Mussels are sensitive to the effect of reactive oxygen species like other aerobic organisms (Winston et al., 1996; Funes et al., 2006). It has been shown that PFC type pollutants alter the levels of antioxidants in mussels (Liu et al., 2014). Glutathione S-transferase (GST) is the important phase II enzyme present in the living organisms. Glutathione S-transferase enzymes are dimeric proteins that have a key role in the detoxification of endogenous and exogenous electrophilic compounds (Mainwaring et al., 1996). Glutathione S-transferase activity measurements have been used in many different studies to monitor contamination level in different marine species. Many pollutants such as dichlorodiphenyl trichloroethane (DDT), Benzo[a]pyrene (BaP), perfluorooctanoic acid (PFOA), perfluorooctane sulfonate (PFOS). are detoxified by glutathione S-transferase enzymes.

The effects of persistent organic pollutants such as PFOS can occur at any different trophic levels. In aquatic toxicological studies to define the effects of toxicants, biomarkers are accepted as highly important tools. They have been used as early warning systems in order to protect environmental damages

In this study, the effects of Perfluorinated compounds (PFOS) on the induction of glutathione S-transferase activity in mussels were examined. 


\section{MATERIALS AND METHOD}

Mussels were collected from the mussel culture facilities in İzmir-Çeşme, and acclimated to artificial seawater for 6 days. After the acclimation process, to evaluate the effect of GST enzyme activity, Mytilus galloprovincialis were exposed to different concentrations of PFOS. In order to test six concentrations of PFOS (2-3-5-6-8-10 ppm), a total of 120 mussels were used. During the experiment, $M$. galloprovincialis were fed daily by addition of $30 \mathrm{ml} / \mathrm{l}$ of Chlorella sp. (approximately 70,000 cells $/ \mathrm{mL}$ ) to each aquarium sized $57 \times 39 \times 28 \mathrm{~cm}$. The mussels were kept by $12 / 12$ light cycle. The water in the aquarium was changed every other day.

At the end of the experiment, the mussels were taken out and shell length and weight were measured by using calipper and digital scale $[6,61 \pm 0,41(\mathrm{~cm}), 24,43$ $\pm 5,01$ (gr)]. To analyze the GST activity, hepatopancreas was dissected from the mussel as fast as possible and scaled. Collected tissues were washed with the phosphate buffer and homogenized in an Ultra Turax tissue homogenizer in homogenization buffer. $300 \mathrm{ml}$ of homogenization buffer contained $1 \mathrm{M} \mathrm{KCl}(45 \mathrm{~mL})$, $100 \mathrm{mM}$ DTT (3 mL), $100 \mathrm{mM}$ EDTA $(3 \mathrm{~mL}), 10 \mathrm{mM}$ PMSF (3 mL), $100 \mathrm{mM}$ phosphate buffer $(200 \mathrm{~mL})$ and $\mathrm{pH}$ 7.4. The homogenate tissue was centrifuged at $10000 \times \mathrm{g}$ at $4^{\circ} \mathrm{C}$ for $30 \mathrm{~min}$ to obtain the postmitochondrial fraction. During the analysis, great attention is required to maintain the entire cold chain

GST activity was measured according to the method of Habig et al. (1974), by following the conjugation of reduced glutathione (GSH) with 1-chloro-2,4dinitrobenzene (CDNB) at $340 \mathrm{~nm}$ for $10 \mathrm{~min}$ at constant temperature using kinetic spectrophotometer (BioTekSYNERGY|HTX). Protein concentration was measured according to the method of Bradford (1976). GST activities were expressed as nmoles $/ \mathrm{min} / \mathrm{mg}$ of $\mathrm{S} 10$ protein (mg P). The differences between samples were investigated one-way ANOVA and Multiple Range Test. The statistical analysis was performed using the Statgraphics software v.16.2 and statistical significance was defined at $p<0.05$ level.

\section{RESULTS}

Hepatopancreas (digestive glands) were taken to determine the effect of various concentrations of PFOS on antioxidant enzyme activities of mussel, $M$. galloprovincialis. The results are presented in Figure 1 for all treatment periods including 7, 15 and 21 days. Levels of GST in control group were ranged between 0.023 and $0.035 \mu \mathrm{mol} / \mathrm{min} / \mathrm{mg}$.

GST activity in hepatopancreas of mussels exposed to lowest concentration ( $2 \mathrm{mg} / \mathrm{L}$ ) increased gradually from 0,027 to $0,044 \mu \mathrm{mol} / \mathrm{min} / \mathrm{mg}$ between the $7^{\text {th }}$ day and $21^{\text {th }}$ day of experiment. Furthermore, in the mussels exposing to $3 \mathrm{mg} / \mathrm{l}$ PFOS concentration had the highest GST activity $(0,074 \mu \mathrm{mol} / \mathrm{min} / \mathrm{mg})$ which was nearly twice of control value at the end of the $21^{\text {th }}$ day of experiment The group exposed to $5 \mathrm{mg} / \mathrm{l}$ PFOS concentration showed similar pattern with slightly decreased value in the 21 day. The GST activity in the mussels exposed to $8 \mathrm{mg} / \mathrm{l}$ PFOS was higher nearly two times compared with control value in $7^{\text {th }}$ day and the value decreased slightly in the next few days. On the other hand, the highest dosage of PFOS $(10 \mathrm{mg} / \mathrm{l})$ caused the lowest GST activity in the mussel when compared to other experimental groups.

GST activity increasing regularly in lower concentrations was statistically significant $(p<0.05)$. The results indicated that in lower concentrations of PFOS, GST activity can be increased. It means that organisms have healthy reaction to metabolizing the contaminants. However, in higher concentrations $(8,10$ $\mathrm{mg}$ PFOS/I), GST values changed irregularly comparing to control group $(p<0,05)$. M. edulis samples exposed to $8 \mathrm{mg}$ PFOS/l showed sharp increase during the first week of the test, but the level lowered gradually afterwards. Unlike to this, the group exposed to $10 \mathrm{mg}$ PFOS/I had the weekest GST activity. This may explaine the toxic effect of PFOS on hepatopancreas of mussel in high concentrations. It seems that they couldn't have enough function to produce the enzymatic activity for protection. This result suggests that the toxic effect of PFOS is increased by restraining the production of enzyme

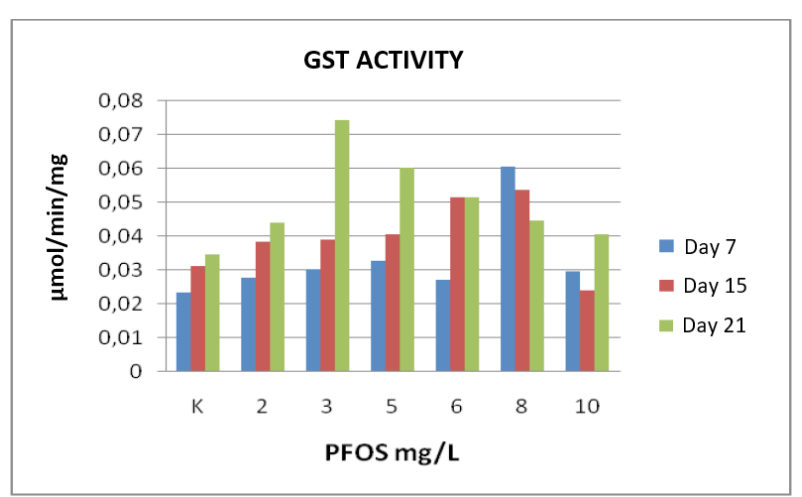

Figure 1. GST activity in the mussels affected by various concentrations of PFOS in the different test periods.

\section{DISCUSSION}

M. galloprovincialis has been commonly used as bioindicator organism in biomonitoring programs (Livingstone, 1998; Cheung et al., 2001; 2002). Because they are filter feeding organisms and they 
bioaccumulate and biomagnify the pollutants (Zhou et al., 2008). Biomarker enzyme activities such as glutathione S-transferase and the other antioxidant enzymes have been studied in different mussel species (Cheung et al., 2004; Power and Sheehan, 1996; De Luca-Abbott et al.,2005).

Hepatopancreas of M. galloprovincialis were used in measurements of enzyme activity as biomarker. Because the hepatopancreas is the major metabolic organ for degrading xenobiotics and the first metabolic reactions on the molecules are achieved by the enzymes involved in biotransformation process in metabolism (Meyer,1996). Previous studies showed that GST in hepatopancreas tissue shows more utility for further investigation than gill tissue (De LucaAbbott et al.,2005)

According to the results of this studies, GST activity ( $\mu \mathrm{mol} / \mathrm{min} / \mathrm{mg}$ ) in mussel exposed to low concentrations of PFOS tended to increase when it compared to the control group ( $p<0.05)$. Similarly, positive correlations were observed between GST activities and POP's in the mussel, M. galloprovincialis collected from Bizerte Lagoon (Tunusia) where GST activity showed a trend of increase with increased toxicant concentration (Barhoumi et al.,2014). Fitzpatrick and Sheehan (1993) reported that GST enzyme activity can be useful indicator of mussel exposed to persistent organic pollutants.

Glutathione-Stransferases (GSTs) are the main enzymes involved in xenobiotic phase II metabolism. GSTs detoxify a number of environmental carcinogens (Gallagher et al., 1996).The measurement of glutathione S-transferase activity is also used as a biomarker of oxidative stress (Rodriguez-Ariza et al., 1993; MartínezGómez et al., 2006).

Organisms exposed to xenobiotics in various ways tend to convert chemicals into a more harmless form (Parlak et al., 2011).The induction of antioxidant enzyme activities represents a cellular defense mechanism to neutralize toxic effects of reactive oxygen species. There are many studies in which these activities are induced by pollutants presented in contaminated waters (Otto and Moon, 1995; Ferreira et al., 2005; Martínez- Gómez et al., 2006). In several studies, it has been shown that

\section{REFERENCES}

Adams, S.M. (2002). Biological indicators of aquatic ecosystem stress. Bethesda, Maryland, USA: American Fisheries Society.

Ahrens, L. \& Bundschuh, M. (2014). Fate and effects of poly- and perfluoroalkyl substances in the aquatic environment: A review. Environ. Toxicol. Chem. 33, 1921-1929. DOI: 10.1002/etc.2663
GST and some antioxidant enzyme activities have high sensitivity to contaminants in mussels (Power and Sheehan, 1996; Winston, et al.,1996). Gowland et al. (2002), reported that high moleculer weight PAHs have more pronounced role in inducing GST activity in mussels.

There are substantial amount of knowledges about the role of GST in aquatic species exposed to xenobiotics. The general aspect is that GST should have prominent position in MFO's as biomarker for ecotoxicological studies (Joselyn et al. 2012). In this study, the results of GST activities of mussel exposed to PFOS also propound that GST can be use as biomarker for studying the effect of pollutants especially in environmentally relevant concentrations.

\section{CONCLUSION}

In this study, mussel hepatopancreas exposed to PFOS in low concentrations, GST enzyme activity had showed a statistically significant increase when compared to the control group. The results showed that protective mechanisms were induced. On the other hand, in the mussels exposed to higher concentrations of contaminant this protective mechanism seemed to be depressed by the toxic action of PFOS. It is necessary to study the mode of toxic action of PFOS on the enzyme system in detail and determine long-term ecological effects of PFOS on aquatic organisms so as to gain important knowledge of the ecological risk of PFOS.

In addition, the susceptibility of $M$. galloprovincialis to various pollutants have been confirmed with toxicological studies. Moreover, the effects of various pollutants far below the lethal concentrations have been emphasized by determining changes in the physiological parameters of organism.

In conclusion, to protect the ecosystem, changes in enzyme activity due to the toxicants can be used as biomarkers. It is important to perform similar studies that will provide early warning signs for protection of species diversity and ecosystem health.

\section{ACKNOWLEDGEMENT}

This master thesis is a part of the Project (Number 114Y386) supported by Turkish Scientific and Technological Research Council of Turkey.

Barhoumi, B., Le Menach K., Clérandeau, C., Ameur, W.B., Budzinski.H., Driss,M.R. \& Cachot J. (2014). Assessment of pollution in the Bizerte lagoon (Tunisia) by the combined use of chemical and biochemical markers in mussels, Mytilus galloprovincialis. Mar Pollut Bull., 15, 84(1-2), 379-90.

DOI: 10.1016/j.marpolbul.2014.05.002

Boudreau, T. M., Sibley, P. K., Mabury, S. A., Muir, D. G. C., \& Solomon, K. 
R. (2003). Laboratory evaluation of the toxicity of perfluorooctane sulfonate (PFOS) on Selenastrum capricornutum, Chlorella vulgaris, Lemna gibba, Daphnia magna, and Daphnia pulicaria. Archives of Environmental Contamination and Toxicology, 44(3), 0307-0313. DOI: 10.1007/s00244-002-2102-6

Boyacıoğlu, M., Arslan, Ö. Ç., Parlak, H. \& Karaaslan, M. A. (2007) Mutagenicity of nonylphenol and octylphenol using Salmonella Mutation assay. EU Journal of Fisheries \& Aquatic Sciences, 24, 3-4.

Bradford, M.M. (1976). A rapid and sensitive method for the quantitation of microgram quantities of protein utilizing the principle of protein-dye binding. Analytical Biochemistry, 72(1-2), 248-254. DOI: 10.1016/0003-2697(76)90527-3

Cheung, C. C. C., Siu, W. H. L., Richardson, B. J., De Luca-Abbott, S. B. \& Lam, P.K.S. (2004). Antioxidant responses to benzo [a] pyrene and Aroclor 1254 exposure in the green-lipped mussel, Perna viridis. Environmental Pollution, 128(3), 393-403. DOI: 10.1016/j.envpol.2003.09.010

Cheung, C. C. C., Zheng, G. J., Lam, P. K. S.,\& Richardson, B. J. (2002) Relationships between tissue concentrations of chlorinated hydrocarbons (polychlorinated biphenyls and chlorinated pesticides) and antioxidative responses of marine mussels, Perna viridis. Marine Pollution Bulletin, 45(1-12), 181-191. DOI: 10.1016/S0025-326X(01)00301-0

Cheung, C. C. C., Zheng, G. J., Li, A. M. Y., Richardson, B. J. \& Lam, P. K. S. (2001). Relationships between tissue concentrations of polycyclic aromatic hydrocarbons and antioxidative responses of marine mussels, Perna viridis. Aquatic Toxicology, 52(3-4), 189203. DOI: $10.1016 / \mathrm{S} 0166-445 \times(00) 00145-4$

De Luca-Abbott, S. B., Richardson, B. J., McClellan, K. E., Zheng, G. J., Martin, M. \& Lam, P.K. (2005). Field validation of antioxidant enzyme biomarkers in mussels (Perna viridis) and clams (Ruditapes philippinarum) transplanted in Hong Kong coastal waters. Marine Pollution Bulletin, 51(8), 694-707. DOI: 10.1016/j.marpolbul.2005.01.010

EPA, U. (2010). 2015 PFOA Stewardship Program. United States Environmental Protection Agency Homepage (2010) http://www. epa. gov/oppt/pfoa/pubs/stewardship.

Ferreira, M., Moradas-Ferreira, P. \& Reis-Henriques, M. A. (2005) Oxidative stress biomarkers in two resident species, mullet (Mugil cephalus) and flounder (Platichthys flesus), from a polluted site in River Douro Estuary, Portugal. Aquatic Toxicology, 71(1), 39-48. DOI: 10.1016/j.aquatox.2004.10.009

Fitzpatrick, P.J., O'Halloran, J., Sheehan, D. \& Walsh, A.R. (1997) Assessment of a glutathione S-transferase and related proteins in the gill and digestive gland of Mytilus edulis (L.), as potential organic pollution biomarkers. Biomarkers 2, 51- 56 DOI: 10.1080/135475097231977

Funes, V., Alhama, J., Navas, J. I., López-Barea, J. \& Peinado, J. (2006) Ecotoxicological effects of metal pollution in two mollusc species from the Spanish South Atlantic littoral. Environmental Pollution, 139(2), 214-223. DOI:10.1016/j.envpol.2005.05.016

Gallagher, E. P., Stapleton, P. L., Slone, D. H., Schlenk, D. \& Eaton D. L. (1996). Channel catfish glutathione S-transferase isoenzyme activity toward ( \pm )-anti-benzo [a] pyrene-trans-7 8-dihydrodiol-9, 10-epoxide. Aquatic Toxicology, 34(2), 135-150. DOI: 10.1016/0166-445X(95)00037-5

Gowland, B. T. G., McIntosh, A. D., Davies, I. M., Moffat, C. F. \& Webster, L. (2002). Implications from a field study regarding the relationship between polycyclic aromatic hydrocarbons and glutathione S-transferase activity in mussels. Marine Environmental Research 54(3-5), 231-235. DOI: 10.1016/S0141-1136(02)00129-0

Gunduz, G., Parlak, H., Arslan, Ö. Ç., Boyacioglu, M. \& Karaaslan, M.
A. (2013). Embryotoxic effects of Perfluorooctane Sulfonate Compounds in sea urchin Paracentrotus lividus. Fresenius Environmental Bulletin, 22(1A), 171-177.

Habig, W.H., Pabst, M.J. \& Jakoby, W.B. (1974). Glutathione S-transferases the first enzymatic step in mercapturic acid formation. Journal of Biological Chemistry, 249(22), 7130-7139.

Han, J., Won, E. J., Lee, M. C., Seo, J. S., Lee, S. J. \& Lee, J. S. (2015) Developmental retardation, reduced fecundity, and modulated expression of the defensome in the intertidal copepod Tigriopus japonicus exposed to BDE-47 and PFOS. Aquatic Toxicology, 165, 136-143. DOI: 10.1016/j.aquatox.2015.05.022

Houde, M., De Silva, A. O., Muir, D. C. \& Letcher, R. J. (2011). Monitoring of perfluorinated compounds in aquatic biota: an updated review: PFCs in aquatic biota. Environmental Science \& Technology, 45(19), 7962-7973. DOI: 10.1021/es104326w

Huang, H., Huang, C., Wang, L., Ye, X., Bai, C., Simonich, M. T., ... \& Dong, Q. (2010). Toxicity, uptake kinetics and behavior assessment in zebrafish embryos following exposure to perfluorooctanesulphonicacid (PFOS). Aquatic Toxicology, 98(2), 139-147. DOI: 10.1016/j.aquatox.2010.02.003

Jemec, A., Drobne, D., Tišler, T. \& Sepčić, K. (2010). Biochemical biomarkers in environmental studies-lessons learnt from enzymes catalase, glutathione S-transferase and cholinesterase in two crustacean species. Environmental Science and Pollution Research, 17(3), 571-581. DOI: 10.1007/s11356-009-0112-x

Jocelyne, H., Ross, N.W. \& Moon, T.W. (2012). Glutathione, glutathione S-transferase, and glutathione conjugates, complementary markers of oxidative stress in aquatic biota. Environ Sci Pollut Res.,19, 2007-2023. DOI: 10.1007/s11356-012-0909-x

Karaaslan, M. A., Parlak, H., Arslan, O. C. \& Boyacıoglu, M. (2012). The embryotoxic effects of beta blocker atenolol on sea urchin Arbacia lixula embryos. Fresenius Enviromental Bulletin, 21(11b), 3362-3364

Katalay, S., Boyacioglu, M., Arslan, O. C., Parlak, H. \& Karaaslan, M. A. (2012). Phytotoxicity of water and sediment from Nif Brook (Izmir, Turkey) on green algae Desmodesmus (= Scenedesmus) subspicatus. Ekoloji, 21(83), 25-31. DOI: 10.5053/ekoloji.2012.833

Kissa, E. (Ed.). (2001). Fluorinated surfactants and repellents (Vol. 97). CRC Press.

Kovarova, J., Marsalek, P., Blahova, J., Jurcikova, J., Kasikova, B. \& Svobodova, Z. (2012). Occurrence of perfluoroalkyl substances in fish and water from the Svitava and Svratka Rivers, Czech Republic. Bulletin of Environmental Contamination and Toxicology, 88(3): 456-460. DOI: 10.1007/s00128-011-0484-8

Kwok, K. Y., Wang, X. H., Ya, M., Li, Y., Zhang, X. H., Yamashita, N., ... \& Lam, P. K. (2015). Occurrence and distribution of conventional and new classes of per-and polyfluoroalkyl substances (PFASs) in the South China Sea. Journal of Hazardous Materials, 285, 389397. DOI: 10.1016/j.jhazmat.2014.10.065

Lindstrom, A. B., Strynar, M. J. \& Libelo, E. L. (2011). Polyfluorinated compounds: Past, present, and future. DOI: 10.1021/es2011622

Liu, C., Chang, V. W. \& Gin, K. Y. (2014). Oxidative toxicity of perfluorinated chemicals in green mussel and bioaccumulation factor dependent quantitative structure-activity relationship. Environmental Toxicology and Chemistry, 33(10), 2323-2332. DOI: $10.1002 /$ etc. 2679

Liu, C., Gin, K. Y. \& Chang, V. W. (2014). Multi-biomarker responses in green mussels exposed to PFCs: effects at molecular, cellular, and physiological levels. Environmental Science and Pollution Research, 21(4), 2785-2794. DOI:10.1007/s11356-013-2216-6 
Livingstone, D. R. (1998). The fate of organic xenobiotics in aquatic ecosystems: quantitative and qualitative differences in biotransformation by invertebrates and fish. Comparative Biochemistry and Physiology Part A: Molecular \& Integrative Physiology, 120(1), 43-49. DOI: 10.1016/S1095-6433(98)10008-9

Mainwaring, G. W., John, N. A. S. H., Davidson, M. \& Green, T. (1996). Isolation of a mouse theta glutathione S-transferase active with methylene chloride. Biochemical Journal, 314(2), 445-448. DOI: $10.1042 / b j 3140445$

Martínez-Gómez, C., Campillo, J. A., Benedicto, J., Fernández, B. Valdés, J., García, I. \& Sánchez, F. (2006). Monitoring biomarkers in fish (Lepidorhombus boscii and Callionymus lyra) from the northern Iberian shelf after the Prestige oil spill. Marine Pollution Bulletin, 53(5-7), 305-314. DOI: 10.1016/j.marpolbul.2006.03.010

Meyer, U. A. (1996). Overview of enzymes of drug metabolism. Journal of Pharmacokinetics and Biopharmaceutics, 24(5), 449459. DOI: 10.1007/BF02353473

Müller, C. E., Spiess, N., Gerecke, A. C., Scheringer, M. \& Hungerbühler K. (2011). Quantifying diffuse and point inputs of perfluoroalkyl acids in a nonindustrial river catchment. Environmental Science \& Technology, 45(23), 9901-9909. DOI: 10.1021/es202140e

Naile, J. E., Khim, J. S., Wang, T., Chen, C., Luo, W., Kwon, B. O., ... \& Giesy, J. P. (2010). Perfluorinated compounds in water, sediment, soil and biota from estuarine and coastal areas of Korea. Environmental Pollution, 158(5), 1237-1244. DOI: 10.1016/j. envpol.2010.01.023

O'Brien, J. M., Carew, A. C., Chu, S., Letcher, R. J. \& Kennedy, S. W. (2009). Perfluorooctane sulfonate (PFOS) toxicity in domestic chicken (Gallus gallus domesticus) embryos in the absence of effects on peroxisome proliferator activated receptor alpha (PPARa)regulated genes. Comparative Biochemistry and Physiology Part C: Toxicology \& Pharmacology, 149(4), 524-530. DOI: 10.1016/j.cbpc.2008.11.009

OECD. (2002). Co-operation on Existing Chemicals Hazard Assessment of Perfluorooctane Sulfonate (PFOS) and Its Salts. Environment Directorate. Joint meeting of the Chemicals Committee and the Working Party on Chemicals, Pesticides and Biotechnology.

Otto,D.M.,\&Moon,T.W. (1995). 3,3',4,4'-TetrachlorobiphenylEffectson Antioxidant Enzymes and Glutathione Status in Different Tissues of Rainbow Trout. Basic \& Clinical Pharmacology \& Toxicology, 77(4), 281-287. DOI: 10.1111/j.1600-0773.1995.tb01028.x

Parlak, H., Arslan, O.Ç., Boyacıoğlu, M. \& Karaaslan, M.A. (2011) Ekotoksikoloji ders kitabı. Ege Üniversitesi Su Ürünleri Fakültesi Yayınları No:79, Ders Kitabı Dizini No:39.

Paul, A. G.Jones, K. C. \& Sweetman, A. J. (2009). A first global production, emission, and environmental inventory for perfluorooctane sulfonate, Environ. Sci. Technol., 43, 386-392.
DOI: $10.1021 /$ es $802216 n$

Peakall, D.B. \& Walker, C.H. (1994). The role of biomarkers in environmental assessment (2). Vertebrates. Ecotoxicology, 3, 173-179. DOI: 10.1007/BF00117082

Power, A. \& Sheehan, D. (1996). Seasonal variation in the antioxidant defence systems of gill and digestive gland of the blue mussel, Mytilus edulis. Comparative Biochemistry and Physiology Part C: Pharmacology, Toxicology and Endocrinology, 114(2), 99-103. DOI: 10.1016/0742-8413(96)00024-2

Prevedouros, K., Cousins, I. T., Buck, R. C. \& Korzeniowski, S. H. (2006). Sources, fate and transport of perfluorocarboxylates. Environmental Science \& Technology, 40(1): 32-44. DOI: 10.1021/es0512475

Rodriguez-Ariza, A., Peinado, J., Pueyo, C. \& Lopez-Barea, J. (1993). Biochemical indicators of oxidative stress in fish from polluted littoral areas. Canadian Journal of Fisheries and Aquatic Sciences, 50(12), 2568-2573. DOI: 10.1139/f93-280

Wang, T., Wang, P., Meng, J., Liu, S., Lu, Y., Khim, J. S. \& Giesy, J. P. (2015). A review of sources, multimedia distribution and health risks of perfluoroalkyl acids (PFAAs) in China. Chemosphere, 129, 87-99. DOI: 10.1016/j.chemosphere.2014.09.021

Winston, G. W., Moore, M. N., Kirchin, M. A. \& Soverchia, C. (1996). Production of reactive oxygen species by hemocytes from the marine mussel, Mytilus edulis: lysosomal localization and effect of xenobiotics. Comparative Biochemistry and Physiology Part C: Pharmacology, Toxicology and Endocrinology, 113(2), 221-229. DOI: 10.1016/0742-8413(95)02091-8

Yamashita, N., Kannan, K., Taniyasu, S., Horii, Y., Petrick, G. \& Gamo, T. (2005). A global survey of perfluorinated acids in oceans. Marine Pollution Bulletin, 51(8-12), 658-668. DOI: 10.1016/j.marpolbul.2005.04.026

Yeung, L. W., So, M. K., Jiang, G., Taniyasu, S., Yamashita, N., Song, M., ... \& Lam, P. K. (2006). Perfluorooctanesulfonate and related fluorochemicals in human blood samples from China. Environmental Science \& Technology, 40(3), 715-720. DOI: $10.1021 /$ es052067y

Zhao, Z., Tang, J., Mi, L., Tian, C., Zhong, G., Zhang, G., ... \& Sun, H. (2017). Perfluoroalkyl and polyfluoroalkyl substances in the lower atmosphere and surface waters of the Chinese Bohai Sea, Yellow Sea, and Yangtze River estuary. Science of the Total Environment, 599, 114-123. DOI: 10.1016/j.scitotenv.2017.04.147

Zhou, Q., Zhang, J., Fu, J., Shi, J. \& Jiang, G. (2008). Biomonitoring: an appealing tool for assessment of metal pollution in the aquatic ecosystem. Analytica Chimica Acta, 606(2), 135-150. DOI: 10.1016/j.aca.2007.11.018 